\title{
When Do Legal Sanctions Produce Conformity? A Review of the Literature on the Interaction of Perceived Legal Risk with Stakes in Conformity
}

\author{
Christopher P. Rosbough
}

College of Criminology and Criminal Justice, Florida State University, Tallahassee, FL, USA

\begin{abstract}
This paper reviews ten published articles on deterrence that address the interaction of stakes in conformity with the perception of legal risk. These articles are classified by types of stakes in conformity examined, such as marriage, education, and employment, and more general types of stakes in conformity, such as social identity. Analysis of evidence suggests that some individuals with low stakes in conformity may be less deterrable by legal sanctions and for those with high stakes in conformity, legal sanctions, such as imprisonment, may increase recidivism. The results, however, continue to show an incongruence between whether and which stakes in conformity act as a consistent deterrent.
\end{abstract}

Keywords: Interaction, Deterrence, Stakes in conformity, Police Domestic Violence, Recidivism, Legal Sanctions.

\section{PRELIMINARY CONSIDERATIONS}

\section{Introduction}

Criminal justice policy has been largely founded on the fact that deterrence forces people to rethink their actions. And the legal environment in the United States regarding domestic violence, for example, is fairly clear regarding deterrence, at least during the last fifteen to twenty years, in that an arrest must be made in probable cause cases of domestic violence. Since the 1960s and 1970s, women's rights (regarding domestic violence as it relates to deterrence theory and criminal justice policy) have become clearer and more important, and since then, police have been consistently pushed to provide more innovative alternatives in such cases. One of theses innovations came in the form of early intervention, especially probable cause arrests. Although early studies found some evidence that arrest produced positive results, this research later muddied the waters (see Schmidt and Sherman 1996 and Sherman and Berk 1984). In fact, authors in several U.S. cities found that counseling was on par with arrest, and non-custodial arrests produced more violence. More strikingly, arrest increased recidivism rates in three of four domestic violence studies, Omaha, Charlotte, and Milwaukee (Schmidt and Sherman 1996). Additionally, arrest increased recidivism rates for those unemployed and dropped recidivism rates for those employed (Sherman et al. 1992). Such confusion has led to a mixed bag regarding current policies requiring arrest, at least in

\footnotetext{
*Address correspondence to this author at the College of Criminology and Criminal Justice, Florida State University, Tallahassee, FL, USA; Tel: (850) 644-4050; Fax: (850) 644-9614; E-mail: cpr09@my.fsu.edu
}

domestic violence cases (which arise largely out of the Minnesota Domestic Violence Experiment or MDVE and Spouse Abuse Replication Program or SARP (see Piquero et al. 2011)). And even though much progress has been made in the realm of these cases (e.g., victim's advocate), a full knowledge of the interaction of legal threats with specific crimes remains scant. In fact, of the many studies of deterrence, only a few go beyond studying the main effects of legal threat on criminal behaviors to assess its conditional effects.

This paper's emphasis on empirical studies does not imply that contemporary approaches to deterrence fail to advance the field. But, the intent of this review is to highlight what can be learned from the few deterrence studies and the interaction effects, some involving domestic violence cases. Furthermore, this review underscores research that identifies the individuals who are most likely to be affected by legal sanctions (i.e., arrest) and those who may be the least affected by legal controls. It has been assumed that people with more to lose (i.e., having more stakes in one's community) will be less likely to recidivate or affected by legal sanctions the most.

This paper investigates the conditional effect of arrest (i.e., the perception of sanction threats on behavior) and how some variables may condition the effect of legal threats on an individual's behavior. In other words, it can be assumed that people who have the most to lose from legal punishment might be most deterred by the threat of legal punishment in what are called stakes in conformity (Toby 1957; Hirschi 1969). Research on deterrence has consistently noted variations in deterrability. Early research on domestic violence suggested that arrest deters abusers with high 
stakes in conformity (see Sherman, et al., 1992 as well as Berk et al. 1993 for extensive discussions regarding arrest and domestic violence). However, later studies found that arrests of high-stakes individuals either increased recidivism or had no effect (Kingsnorth, 2006; Spohn, 2007). Other studies found no effect of arrest, regardless of whether the offender has low or high stakes in conformity (Berk, Campbell, Klap, and Western 1992; Nagin and Pogarsky 2001, 2003). Deterrence-centric policies, however, have been subjected to criticism regarding which punitive methods reduce crime. Arrests that lead to imprisonment have been of central concern, since critics argue that arrests and those leading to incarceration have done little to reduce crime. Imprisonment can include temporary stays in jail facilities, such as those individuals who are awaiting trial, cannot post a bond, or are remanded to temporary incarceration for domestic violence, as is the case in Florida. More importantly, according to Nagin, Cullen, and Jonson (2009), "...offenders might expect that an arrest might bring, with much greater certainty, a harsher prison sentence, and hence be more susceptible to specific deterrence" (pg. 124). This sentiment has been echoed in several research articles, including those by Tonry and Petersilia (1999). Critics have also argued that the United States imprisons too many people who should never have been incarcerated. McGuire and Priestly (1995) concluded that punitive measures, like imprisonment, actually increase the rates of recidivism. Vieraitis, Kovandzic, and Marvell (2007) claim that prisons had negative outcomes, where the "coefficients for the prison release rate variable are in the expected positive direction and [were] statistically significant" (Vieraitis, et al., 2007:606).

Although this paper focuses on domestic violence and other crimes with subsequent arrests, what happens after arrest is also important, and it should be noted that negative outcomes of arrest might include such sanctions, especially for first-time and repeat offenders. If legal sanctions have negative effects on crime, then it is important to understand that placing legal controls on some segments of the population may increase their criminal behavior. More importantly, the effects of imprisonment on people with high stakes in conformity may not deter crime, but instead may sever the bonds to society, increasing the likelihood of further criminal behavior. As a likely outcome, placing people with bonds to society in prison may exacerbate their positions in life and any stakes in conformity may quickly deteriorate in prison. Thus, the reason for this paper is to move deterrence research to emphasize the need to empower findings with interaction effects, something that is relatively rare in this type of research.

This paper may help to clarify some of the issues in the field of deterrence with regard to stakes in conformity and the impact of legal threat. Further, the review will emphasize the importance of going beyond the study of main (or additive) effects to include interactions of legal risk and stakes in conformity. A review of the preliminary background on stakes in conformity and deterrence will precede the presentation of ten empirical studies, after which some conclusions will follow in the area of deterrence, perceptions of legal risk, and stakes in conformity as it regards to domestic violence.

\section{What Are Stakes in Conformity}

Even though a litany of research has been performed regarding deterrence studies, little progress has been made to fully understand the theory's complexity. Indeed, deterrence research has been founded on general and specific deterrence and related effects on criminal behavior (think of President Clinton's initiative to place 100,000 additional police officers on U.S. streets via the Violent Crime Control and Law Enforcement Act). Levitt (2004) maintains this correlated to lower crime rates, but his supposition is highly in doubt (see Eck and Maguire 2006). Yet, the principle deterrence premises have been under scrutiny for years. According to Raymond Paternoster (2010):

\section{While we have an abundance of research about specific police, judicial, and correctional policies, as well as more general theoretical work about deterrence mechanisms, the evidence to date, while suggesting that there is a deterrence return to all that we do about crime, is more than a little flimsy (p. 766).}

Needless to say, the scope must be broadened to include a relationship between related variables that more than likely fall within its scope, such as stakes in conformity and related interaction that provide more powerful evidence to a deterrent effect. When considering deterrence and its effectiveness, researchers should bear in mind that the theory's effectiveness relies on some semblance of getting people to conform (i.e., social control). Such social control is important, since it literally forces us to abide 
by some societal standard (i.e., law). For example, Pate and Hamilton (1992) looked at whether employment countered the effects of arrest, which their findings confirmed. Commitment to some long-term activity is generally considered a stake in conformity, such as relationships, educational endeavors, or careers. Howard Becker (1960:33) noted that a stake in conformity is " ...an activity that persists over some period of time...in the pursuit of the same goal." Goals vary, but the general thought includes some progress of an activity or activities that hold themselves responsible to a larger purpose that shows consistency. Hirschi (1969) used the term commitment to describe a person's commitment to a long-term line of conventional activity, such as a career. Further, Hirschi (1969) noted that the controls or constraints acting on individuals and preventing deviance are found in their bonds to conventional society. Deviance occurs when "[an] individual's bond to society is weak or broken" (Hirschi 1969:16). It seems reasonable to believe that the more a person has to lose, the less likely he or she is to participate in deviant behavior for fear of the possible consequences. In both Howard and Hirschi's conception of commitment, such commitment includes people that serve the larger goal, be it deviance or conformity. The more one includes deviant peers, for example, commitment may involve criminal lifestyles (i.e., lose the criminal lifestyle and one loses status among peers). In studies of domestic violence and whether legal controls would deter certain types of people, Sherman (1992) and Sherman, et al. (1992) observed that arrest seemed to have a stronger deterrent effect on offenders with a greater stake in conformity. Briar and Piliavin (1965) elaborated on Toby's (1957) idea of stakes in conformity with their idea of "allegiance to the dominant values of a larger society" in their study regarding delinquency:

Commitments to conformity [create] fear of the material deprivations and punishments which might result from being discovered as an offender but also apprehension about the deleterious consequences of such a discovery on one's attempts to maintain a consistent self image, to sustain valued relationships, and to preserve current and future status and activities (39).

Both studies argued that individuals have anchors to dominant social values, to which most people fear losing if ever confronted with criminal sanctions, temporary or permanent. These anchors provide deterrence mechanisms that may prevent criminal behavior (and delinquency), and the risks associated with arrest may indeed be more than enough to deter crime.

The discussion of stakes in conformity should include the consequences of criminal sanctions, because when an arrest is made, a cascade of events occurs. Legal sanctions may range from probation to imprisonment and from home detention to the removal of rights, such as voting and driving. An increase in stakes in conformity would logically mean that legal punishments have a larger effect on one's ties to society. When someone gains lawful employment, for example, a stake in conformity is created. In domestic violence studies, employment and marital status have been factors suspected of moderating the deterrent effect of legal punishment in reducing criminal behavior. These stakes have more power than one might suspect. For example, Pate and Hamilton (1992:695) found that "arrests for spouse assault reduced recidivism only for offenders who were employed and married, that is, for whom public opinion would have more severe consequences." Other evidence exists supporting these findings. Piquero, et al. (2002) followed 524 young offenders for 7 years after release from the California Youth Authority. They used a "stakes in conformity index" based on employment information and marital status-those unemployed and unmarried received a score of 0 and those with both received a score of 2 . Although not explicitly the effects of employment, they concluded that the association between arrests and stakes in conformity was relatively small but statistically significant (Skardhamar and Telle 2012:5).

An arrest should be defined as a legal punishment, as police departments have policies that encourage arrest, especially in domestic violence situations, and immediate effects often occur (Baumer, Felson, and Messner 2003). A marriage can be threatened by a spouse's arrest and its consequences, and the financial ramifications may be significant, especially for people employed full time. The hypothesis suggests that as income rises, so should the fear of losing income. Conversely, people on the lower rungs of the socioeconomic ladder should have less incentive to abide by the rules of society and have little financial incentive to avoid criminal ventures. Regardless, financial hardships because of arrest may create division within the marriage, for example, and subsequent imprisonment can be crushing as the financial incentive rises. For significant others who 
depend on the financial resources of the arrestee, time served in custody may eliminate any financial cushion. Should an offender remain in custody for many years, months, or days, the financial system that was established via the marriage can diminish for every day the offender serves time. Additionally, someone who is employed and then arrested may face termination, especially if employment is contingent on one's character or moral judgment. People working in bluecollar sectors are especially susceptible to termination because of arrest. They often have little paid time off, so every day the offender is not at work places employment in jeopardy. Since blue-collar workers' bonds to society may be more tenuous, they are more often the victims of legal sanctions than are their whitecollar counterparts.

Though, individuals higher in socioeconomic status can also be affected. Friends may keep their distance from a person who faces arrest, since friendships are often based on trust and legitimacy. White-collar workers' friendships are often based on status, so arrest may compromise one's reputation within the community. If one's reputation is sullied, it may become difficult to maintain employment, a marriage, and the financial resources needed to remain successful. Removing the resources of a person's life threatens the foundation on that person's livelihood. As punishment becomes more severe, it can become even more difficult for a person to regain his or her financial, social, and personal footing. Regardless of the outcome, the act of arrest (and temporary detention) may have lasting effects.

Students, too, have a significant amount to lose from arrest. Education has been shown to increase income, increase employment opportunities, and increase the choices that are open to a person. If educational prospects are dimmed, the range of choices may be equally limited. If a student faces repercussions from an arrest, his or her path to success may be hindered. Important is the understanding that each stake in conformity completes a whole picture as to why people may be deterred from committing criminal acts. According to Briar and Piliavin (1965), "A youth with strong commitments to conformity is less likely to engage in deviant acts than is one for whom these commitments are minimal" (39). The more one has to lose, the less likely a person is to participate in criminal activity, or so the hypothesis would assume. For people with higher stakes in conformity, an arrest brings more cost than just legal punishment-it also brings loss of a good job, income, reputation, and friends. Therefore, the threat of arrest stimulates more fear and had a greater deterrent effect for a high stakes in conformity person. As a person ages, the stakes in conformity evolve and become a central component of his or her life.

\section{EMPIRICAL WORK ON LEGAL SANCTIONS AND CONFORMITY}

This review examines studies of interactions among stakes in conformity, types of punishment, and criminal behavior. The dependent variable in each study was the threat or the personal experience of arrest or capture. The independent variable was the behavior. A research finding was relevant to this review if it tested whether the effect of the threat of punishment on crime differed among individuals based on their stake in conformity.

\section{Sampling}

This literature review concerns research that did not merely test for the "main" or additive (non-interactive) effects of punishment on crime, but this study aims to gain a better understanding of how stakes in conformity might condition the effect of punishment on criminal behavior. Although numerous studies analyzed the main effects of punishment, few studies have examined the interactive effects of types of stakes in conformity and the threat of punishment (i.e., certainty and severity). These interactive effects, we believe, provide a more complete picture of when and where the threat of legal punishment is effective in deterring domestic violence. Although the review covers only ten studies, we believe they comprise the bulk of the recent research on this topic. The relative small number of applicable studies examined in this paper limited the extent of the results. However, after a thorough research period, these studies were the only studies that considered interaction effects. While a litany of studies may have been empirically germane to the subject matter, these studies did not provide interaction effect results, at least not the ones applicable to this study.

\section{Methodology for Locating Studies}

Relevant studies were discovered using these online databases: Criminal Justice Periodical Index, National Criminal Justice Reference Service Abstracts database (NCJRS), Psychinfo (Illumina), Web of Science, and Econlit. Basic and advanced searches were used to maximize results. The search terms vital to the review were: stakes in conformity, conformity, stakes, control, deterrence, direct control, social bonds, 
bonds, legal risk, perceived legal risk, social control, legal control, deviance, tax evasion, corruption, evasion, crime, delinquency, rational choice, impulsivity, present-oriented people, self control, impulsivity, marginal offenders, and legal consequences. These terms were searched in the title and abstract fields of the bibliographic entries. Furthermore, a thorough review of the bibliographies from the initially identified studies was conducted. Relevant studies were identified through abstract reviews and additional database searches. Analyses of data of each study were reviewed to determine whether relevant interactions were assessed. Articles, in English, were reviewed from 1980 forward, to include studies that were most relevant to the present.

\section{The Classification of the Material}

Tables 1 and 2 summarize the ten identified studies in chronological order. Each summary describes (from left to right) the samples studied, crime types analyzed, deterrence variables, the conditioning variables (i.e., the specific type of stake in conformity), and the findings. In each study, coefficients for deterrence variables that were multiplied by the conditioning variables comprised the interactive findings. Most studies used a one-tailed test. In cases where a twotailed test was used, the p-value was divided by two to represent a one-tailed significance.

\section{Conditioning Variables}

Operationalizing the conditioning variables varied by study. As stated by Nagin and Pogarsky (2001),
"We...develop several novel techniques for measuring the discount rate and placing a monetary value on the legal and extralegal consequences of criminal behavior" (866). Nagin and Pogarsky borrow from Gottfredson and Hirschi's (1990) "here and now" orientation and Hernstein's (1985) operationalization of impulsivity. These all form their discount rate, as each individual was assigned a discount "score" that measured discounting levels of their present orientations. Wright et al. (2004) conceptualized selfperceived criminality as, "analyzing three separate measures of criminal propensity: low self- control in childhood, low self-control in adolescence, and selfperceived criminality" at various ages, borrowing from Rutter, Tizard, and Whitmore's (1970) Rutter Behavioral Scales as well as others (Wright et al. 1999; Costello et al. 1982; McGee et al. 1992). Kingsnorth's study (2006) measured marriage and employment simply whether one was either at the time of study. Spohn (2007) created a scale of stakes in conformity, where individuals with low stakes had no stakes in conformity measures, including marriage and employment. Mathews and Agnew (2008) operationalized their interaction of peer relationships as the level of delinquent peer association. Finally, Maxson, Matsuda, and Hennigan (2009) measured the conditioning variable, gang affiliation, in much of the same manner. The belief in including such a study (and studies like it) in this review is conformity has the propensity to take on a number of different modes, legal and otherwise. What those in gangs have to lose is status, respect, authority, and possibly money. Take a gang member, for example, out of an environment

Table 1: Studies of the Effect of the Personal Experience of Arrest (with Conviction)

\begin{tabular}{|c|c|c|c|c|c|c|}
\hline Study & Sample & $\begin{array}{l}\text { Independent } \\
\text { Variable }\end{array}$ & $\begin{array}{l}\text { Dependent } \\
\text { Variable }\end{array}$ & $\begin{array}{l}\text { Conditioning } \\
\text { Variable }\end{array}$ & Findings & Control Variables \\
\hline $\begin{array}{l}\text { Sherman, et } \\
\text { al. (1992) }\end{array}$ & $\begin{array}{l}1,200 \text { cases of } \\
\text { misdemeanor } \\
\text { domestic battery. }\end{array}$ & $\begin{array}{l}\text { Domestic } \\
\text { Violence }\end{array}$ & Arrest & $\begin{array}{c}\text { Black } \\
\text { High School } \\
\text { Employed } \\
\text { Marriage }\end{array}$ & $\begin{array}{c}\mathrm{p}<.05 \\
\mathrm{p}<.05 \\
\mathrm{p}<.05 \\
\mathrm{NS}\end{array}$ & 2 \\
\hline $\begin{array}{l}\text { Sherman and } \\
\text { Smith (1992) }\end{array}$ & $\begin{array}{l}1,200 \text { cases of } \\
\text { misdemeanor } \\
\text { domestic battery }\end{array}$ & $\begin{array}{l}\text { Domestic } \\
\text { Violence }\end{array}$ & Arrest & $\begin{array}{c}\text { Employed } \\
\text { Marriage } \\
\text { Employed and } \\
\text { Marriage }\end{array}$ & $\begin{array}{c}\mathrm{p}<.05 \\
\mathrm{NS} \\
\mathrm{p}<.01\end{array}$ & 2 \\
\hline
\end{tabular}


Table 2: Studies of the Effect of Perceived Certainty of Capture and/or Severity of Punishment on Criminal Behavior

\begin{tabular}{|c|c|c|c|c|c|c|}
\hline Study & Sample & $\begin{array}{l}\text { Independent } \\
\text { Variable }\end{array}$ & $\begin{array}{l}\text { Dependent } \\
\text { Variable }\end{array}$ & $\begin{array}{l}\text { Conditioning } \\
\text { Variable }\end{array}$ & Findings & $\begin{array}{c}\text { Control } \\
\text { Variables }\end{array}$ \\
\hline $\begin{array}{c}\text { Nagin and } \\
\text { Pogarsky (2001) }\end{array}$ & $\begin{array}{c}252 \text { University of } \\
\text { Arizona undergraduate } \\
\text { students }\end{array}$ & DUI & $\begin{array}{l}\text { PC X PS } \\
\text { Vignette }\end{array}$ & $\begin{array}{l}\text { Discount Rate } \\
\text { Negative } \\
\text { Discounter }\end{array}$ & $\begin{array}{l}\text { NS } \\
\text { NS }\end{array}$ & 5 \\
\hline $\begin{array}{l}\text { Wright, et al. } \\
(2004)\end{array}$ & $\begin{array}{l}\text { Longitudinal Study } \\
\text { with } 1,002 \text { members }\end{array}$ & $\begin{array}{c}\text { Various Criminal } \\
\text { Behaviors }\end{array}$ & $\begin{array}{c}\text { PC } \\
\text { Arrest } \\
\text { Social Sanction }\end{array}$ & $\begin{array}{l}\text { Self-perceived } \\
\text { criminality }\end{array}$ & $\mathrm{p}<.025$ & 2 \\
\hline $\begin{array}{l}\text { Kingsnorth } \\
\text { (2006) }\end{array}$ & $\begin{array}{c}872 \text { cases of } \\
\text { misdemeanor } \\
\text { domestic battery }\end{array}$ & Domestic Violence & $\begin{array}{c}\text { PS } \\
\text { Re-arrest }\end{array}$ & $\begin{array}{c}\text { Marriage and } \\
\text { Employment }\end{array}$ & NS & $\begin{array}{l}\text { None } \\
\text { Stated }\end{array}$ \\
\hline Spohn (2007) & $\begin{array}{l}1,077 \text { drug and non- } \\
\text { drug offenders }\end{array}$ & $\begin{array}{l}\text { Non-drug/drug } \\
\text { Offenses }\end{array}$ & $\begin{array}{c}\text { PC X PS } \\
\text { Arrest and } \\
\text { Imprisonment }\end{array}$ & $\begin{array}{l}\text { Low Stakes } \\
\text { Minimal Stakes } \\
\text { High Stakes }\end{array}$ & $\begin{array}{c}p<.05 \\
N S \\
p<.05\end{array}$ & 6 \\
\hline $\begin{array}{l}\text { Mathews and } \\
\text { Agnew (2008) }\end{array}$ & 1,625 students & $\begin{array}{l}\text { Property Damage, } \\
\text { Shoplifting, } \\
\text { Marijuana Use, } \\
\text { and Liquor } \\
\text { Violations }\end{array}$ & $\begin{array}{c}\text { PC } \\
\text { Arrest }\end{array}$ & Peer Relationships & $\begin{array}{l}\text { NS } \\
\mathrm{p}<.05 \\
\mathrm{p}<.05 \\
\mathrm{NS}\end{array}$ & 5 \\
\hline $\begin{array}{l}\text { Maxson, } \\
\text { Matsuda, and } \\
\text { Hennigan } \\
(2009)\end{array}$ & 744 Adjudicated Youth & $\begin{array}{l}\text { Larceny } \\
\text { Marijuana } \\
\text { Auto Theft }\end{array}$ & $\begin{array}{c}\text { PC X PS } \\
\text { Arrest and } \\
\text { Imprisonment }\end{array}$ & $\begin{array}{l}\text { Gang Member } \\
\text { Identification }\end{array}$ & $\begin{array}{c}p>.05 \\
N S\end{array}$ & 3 \\
\hline
\end{tabular}

that produces those benefits because of legal consequences, and someone takes his place, where money and authority may be lost. Researchers can debate whether such events certify as having stakes in conformity, but few can argue that there are benefits to nearly all situations like it.

Whether affiliation is based on conventional goals or unconventional goals, both accomplish similar ends. Jackson Toby (1957) alluded to this in his original manuscript. Those juveniles that have low stakes in conformity conform to a different set of standards, those that fall outside of the normal parameters of society. And while these standards meet different approaches to acceptance, delinquents are conforming nonetheless, as they still have something to loserespect and authority among others (see Briar and Pilivan 1965 and subculture theories; Hirschi's (1969) idea that conformity to anyone will foster such; Hansell and Wiatrowski's (1981) idea of the social ability model (and subsequent social learning model); Cressey (1978)). The most common deviant adaptation is innovation, which may lead to criminal behavior (Merton 1938; Agnew 1992). This occurs when an individual believes in the cultural goals but replaces the means with illegitimate ones. This can include stealing instead of working to attain financial success. The point here is that anyone with something to lose risks social alienation, a loss of status, and other benefits attached to any social dynamic.

\section{Control Variables}

The final column in tables one and two represent the number of control variables in each study. Most studies controlled for typical variables, such as race and gender. Two studies did not intimate control variables, but their analyses in large part were based on previous studies that did use control variables, such as those mentioned in the tables.

\section{RESULTS}

The results are presented in Table $\mathbf{1}$ and Table 2. Table 1 represents the personal experience of arrest, in which all cases are for domestic violence. Conditioning variables are also represented. The findings in Table 1 are generally split, nearly half being unsupportive of authors' original findings and a little over half the 
results being supportive of the authors' hypotheses. It would appear that employment, including economic status, had the predicted outcome, while marriage appeared to contradict findings. Education appeared mixed. Though, as noted earlier by Cho and Wilke (2010), marriage had a positive effect in their study.

Table 2 depicts the effect of perceived certainty or severity of punishment on criminal behavior. Types of crime varied and included driving while under the influence of intoxicants, domestic violence, and drug and nondrug offenses. Again, the results are mixed, being split nearly equally. Of those predicted outcomes that were confirmed, six cases showed relevance. In seven cases, the authors' hypothesis was unconfirmed. There appeared to be no consistent finding between perceived certainty and perceived severity, though a slight tilt in favor of perceived certainty was observed.

\section{Arrest as a Deterrent Variable}

Because of the extensive literature on domestic violence, the importance of underscoring the findings and possible patterns in this type of crime seems fitting. In several domestic violence experiments, researchers found that among individuals with a high stake in conformity (married and employed), arrest reduced the annual rate of subsequent violence per suspect (Sherman \& Smith, 1992). However, these researchers also discovered that arrest increased recidivism for people who had low stakes in conformity. It appears that incarceration breaks the societal ties that are so essential to the livelihood of high-stakes people. Longer terms of incarceration may also weaken the anchors to the community, employment, family, and friends.

Kingsnorth (2006), Sherman and Smith (1992), Pate and Hamilton (1992), and Sherman and others (1992) have found that marriage has no effect on criminality. Kingsnorth (2006) did not find stronger deterrent effects of punishment threats among married people. Furthermore, Sherman and Smith (1992) found no differences in the deterrent effect of arrest on domestic violence between married and unmarried people. However, employment appears to strongly condition the effect of arrest on recidivism, as highlighted in studies by Sherman and Smith (1992), Pate and Hamilton (1992), and Sherman and others (1992). These findings are consistent with hypotheses that arrest would deter offending behavior more strongly for employed people for whom the stakes are higher.
In Sherman and Smith's study of domestic violence (1992), marriage and employment appeared to condition the effect of perceived risk of arrest. In Wooldredge and Thistlehwaite's research (2002), education and stable residence were found not to condition the effects of punishment, but economic status (e.g., full-time employment in a skilled profession not receiving public assistance) was statistically significant at .05 and was shown to condition the effects of punishment. However, such effects were in the opposite hypothesized direction; jail and or probation increased rearrest of those individuals on higher levels of economic status, while individuals of lower economic strata were less likely to be rearrested. Here, arrest appeared to have a criminogenic effect on people of higher socioeconomic levels while those lower on the economic ladder were unfazed by arrest. This conclusion confirms the notion that once ties have been severed to one's community, little incentive remains to follow the rules.

Conversely, Sherman and Smith observed, "arrested persons who lacked a stake in conformity were significantly more likely to have a repeat offense than their counterparts who were not arrested. Among those who were married and employed, arrest deterred subsequent violence" (1992:686). Sherman and Smith (1992) offered a possible explanation for an increase in recidivism for low-stakes individuals:

With little to lose, offenders with low stake in conformity may have no reason to suppress their anger and may even have much to gain...violence may be a lastditch strategy to ward off the shame of being cut "down to size" by anyone, including the victim or police (688).

They also reanalyzed results from two domestic violence studies in Omaha and Milwaukee. The original Milwaukee study conducted by Sherman and others (1992) found "no evidence of an overall long-term deterrent effect of arrest." Both the original study and the reanalysis found increases in recidivism for those with low stakes in conformity after the initial arrest. Nonetheless, results from Omaha and Milwaukee reach similar findings to two other domestic violence experiments conducted in Colorado Springs and Dade County. Pate and Hamilton (1992) found that among unemployed suspects in Dade County, increases in recidivism were associated with arrest, supporting the original hypothesis. No significant differences in the 
interaction effects between arrest and marital status were found.

A later study of domestic violence noted contrary results to those of Sherman and Smith, Pate and Hamilton, Demaris and Kaukinen, and Spohn. Wooldredge and Thistlethwaite (2002), for instance, discovered that probation and jail for low-stakes offenders reduced recidivism, while probation and jail resulted in higher rates of rearrest for offenders in the higher stakes strata (high stakes was measured by residential stability, education and economic status, while low stakes was measured without these variables). Thus, the pattern of results was the opposite of what our hypothesis predicted-greater deterrent effects for persons with lower stakes in conformity. Although the authors did not address possible reasons for these results due to space constraints, people with higher stakes in conformity may suffer the consequences of the labeling effect, as stated by Sherman and others. At the same time, legal threats may deter high stake persons who have more to lose more effectively. Conversely, legal threats may be less effective for high conforming people who would not normally commit crime anyway because of their high stake status. The authors did provide a possible interaction between employment and stakes in conformity. According to Wooldredge and Thistlethwaite "...more severe court sanctions administered to offenders with low stakes in employment might be more effective for reducing rearrest relative to the same dispositions administered to offenders with high stakes in employment...suggesting a possible deterrence effect of formal controls when informal controls are weak" (2002:62). Sherman and Smith (1992) also noted that people with low stakes in conformity may be accustomed to being labeled, thus negating stigmatization effects.

Work in the field of domestic violence has been extensive. However, research by Sherman and others has failed to create a solid foundation for policy and other research. Although early research finds deterrent effects for people with high stakes in conformity, later studies arrived at inconclusive or contrary results. For example, Sherman and others noted striking differences in how stakes in conformity condition the effects of arrest. The Milwaukee experiment, though, yielded findings that may have been biased because the sample consisted mainly of low-stakes individuals, which past research has shown have higher levels of recidivism than people with high stakes in conformity. Similar concerns have been raised with other domestic violence studies, raising questions about their generalizability. Although Spohn (2008), Pate and Hamilton (1992), and Sherman and Smith (1992) observed increased recidivism rates after arrest for people with low stakes in conformity, the work of Wooldredge and Thistlethwaite (2002:62) contradicted those findings, "...sentences of probation and/or jail coincide with significantly lower re-arrest likelihoods for offenders lowest on the economic status scale whereas these sentences correspond with significantly higher re-arrest likelihoods for offenders highest on the scale." Reanalyses were also performed by Berk et al. (1992), who concluded that "[the] balance of statistical evidence from Omaha, Milwaukee, and Colorado Springs suggests that arresting suspects in incidents of spousal violence has a deterrent effect for at least a large and identifiable subset of 'good risk' suspects" [those who were employed at the time of study)] (198).

Wooldredge and Thistlehwaite noted that people with low stakes in conformity showed lower recidivism rates after more severe court sanctions, while people with higher stakes had increased recidivism rates with the same punishment assessed. The authors questioned the findings and suggested further research. High-stakes individuals might have had higher rearrest rates because a jail or probation sentence severed or weakened specific ties to one's communities or affected his or her resources. Individuals with low stakes supposedly have less to lose from punitive measures, so they may suffer less from court-ordered sanctions.

Another reason proposed by Wooldredge and Thistlehwaite (2002) may be more substantial: "Unemployed offenders may simply have more opportunities to victimize their partners, opportunities that could be reduced through conditions of probation requiring full-time employment" (65). Wooldredge and Thistlewaite have suggested further research into why their research has contradicted other findings, like why people with high stakes in conformity suffer an increased rate of recidivism.

\section{Certainty and Severity}

Much of the earlier work on deterrence theory focused on the perceptual beliefs of certainty of arrest and severity of sanction, which found overall support (Paternoster 1987). Early studies found perceived certainty of punishment to be "related inversely to various forms of misconduct. With only a few exceptions, all the reported associations are negative 
in sign, indicating that low perceived certainty of punishment is related to the commission of offenses" (Nagin 1987:176). Perceptual properties of severity have received little attention compared to certainty studies, primarily due to inconsistent findings. Severity has taken different connotations, but it primarily relies on the severity of sanctions (i.e., mandatory minimums, length of sentences, etc.). Even today, severity research lacks in strength and empirical support (Baumer 2011).

Maxson and others (2009) found that perceived certainty of punishment had a stronger deterrent effect on auto theft among gang members than it did among non-gang youth. The interaction between gang membership and perceived certainty was significant in this case. Other crimes, like larceny and marijuana use, showed no such effect among gang members. Gang membership did not appear to condition the effects of perceived certainty of arrest in liquor law violations or property crimes. The authors found that higher delinquency among peers fosters an increase in offending, where perceived certainty of arrest fails to deter these juveniles. Generally, in five out of six findings, the authors found that the effects of perceived legal risks were not conditioned by gang membership.

Spohn (2007) measured stakes in conformity with an additive scale that sums the offender's employment status, marital status, responsibility for dependent children, and educational level. These offenders are assessed one point for each stake they possess (e.g., high stakes in conformity is worth four points). The type of stakes in conformity is reported as the "conditioning variable." Most often, the research has defined stakes in conformity as the combination of marriage and employment. In other studies, stakes in conformity may have been defined differently. Spohn found that imprisonment increased the overall recidivism rates for felony-convicted drug and non-drug offenders. In other words, stakes in conformity did not appear to condition the effect of perceived risk of arrest. Wright and others (2004:298) found opposite outcomes, wherein the "deterrent effect [of] getting caught was greatest among study members low in self-control and high in selfperceived criminality, contrary to our hypothesis" (emphasis added). Their study's finding was statistically significant in the negative direction at .05 on a two-tailed test.

Spohn (2007) went further in testing the interactions between one's stakes in conformity and deterrence. She investigated the effects of deterrence in low-, minimal-, and high-stakes groups. Stakes in conformity was defined by four variables: employment, marital status, children, and education. An additive scale was used where each stake in conformity was assigned one point. Those individuals scoring two through four points were assigned a high-stakes label. Those with zero points were assigned a low-stakes label. Those with one point were assigned the label of minimal stakes. Spohn's sample consisted of drug-related offenders as well as non-drug offenders. She found no differences in the deterrent effect of imprisonment on recidivism across these stakes in conformity groups.

Finally, Mathews and Agnew looked to peer relationships as the conditioning variable. Similar results were discovered where the "perceived certainty does not have a deterrent effect on offending among those with a high proportion of delinquent peers" (Mathews \& Agnew 2008:109). The broad measure of stake in conformity regarding relationships was considered with the former cases, since these relationships often provide similar attachments to one's community.

Although marriage alone does not appear to have conditioned the effect of arrest on recidivism rates, stable employment and marriage showed promise as conditioning factors. Kingsnorth (2006) concluded that marriage and employment failed to condition the effect of the perceived risk of arrest. Wright and others (2004) found that present-oriented individuals are easily deterred by threats of sanction threats. Simply stated, certain individuals may be more affected by arrest than others.

\section{CONCLUSIONS AND IMPLICATIONS}

Because of the extremely small examples of interaction effects in this area, it was difficult to identify a particular effect that deterred criminal behavior; more studies should incorporate moderating variables that condition the effects of stakes in conformity. The perceived certainty of arrest may lead to an understanding of which individuals are more deterrable and what stakes in conformity have the largest aggregate effects. For example, employment seemed to have more promise than marriage in deterring criminal behavior, particularly domestic violence. Sherman et al. (1992), Pate and Hamilton's study of domestic violence (1992), and studies by Sherman and Smith (1992) all found statistically significant findings between arrest and employment. Marriage alone, however, did not condition the effects of arrest on 
domestic violence. Employment may provide stability to one's life, limiting the opportunities for criminal activity. Economic ties to employment may bind one to a certain economic lifestyle, and the threat to one's lifestyle more provide for increased conformity. However, these findings also appear mixed, with no uniform determination of which stakes in conformity are the best deterrents. Although employment showed initial promise, Spohn (2007) found that arrest rates actually increased for those employed, placing the deterrent effect of arrest in doubt for those employed supporting the stigmatization effect. Though, as noted earlier, for those with high stakes in conformity, an arrest may loosen the anchors that ground individuals to 'their neighborhoods, giving them an increased predilection for crime. Once people lose those attachments, they may find new obstacles in restoring them.

The certainty of arrest appears to have more promise than severity in most cases, but these results also seemed inconclusive. Certainty may be more of a deterrent to more impulsive individuals since impulsive people tend not to think about the consequences of their actions. If certainty of arrest was to increase considerably, such discounting may be affected to where certainty of a consequence would be inevitable. However, such certainty would need to be consistent.

From the empirical literature that measures the interactive effects of punishment and stakes in conformity, it appears that more stakes in conformity tend to decrease the likelihood of crime. Other studies, however, have presented evidence that observed increases stakes in conformity equaled significant deleterious effects, such as increased criminal behavior, as confirmed by Spohn (2007). In other words, the more one has to lose, the greater chance of severing such ties, which may open a portal for criminal deviance. This information can be used to test the interactive effects of these variables, as only a few studies have focused on these effects.

\section{Limitations}

One of the strongest limitations with this review was its scope-too few studies were found to truly understand interactive effects and deterrence. However, this paper did reveal the lack of attention to interactive effects and deterrence research. While some attention has been given to this type of research (see Wenzel (2002) for his study on tax evasion and interaction effects of severity and social norms), it remains largely ignored. Thus, the area of focus was itself limiting.
Included in this study was research that reviewed a study that addressed gang affiliation. It can be argued that such a study is beyond the scope of this research. Though, it can also be argued that such a study provides valuable insight into a subcultural theoretical understanding of how those that affiliate in gangs developed different forms of stakes in conformity. Conformity is just that, agreeing to a set of standards, which can take the form of legal and extralegal means. If a gang member loses status by legal consequences, that member loses something and risks disassociation with the group (e.g., long prison stays may pave the road for a loss of relevance). This discussion should parlay itself in deterrence research and stakes in conformity and whether such a loss prevents serious criminal behavior or other behavior that might merit police attention.

\section{Future Research}

Future research should focus on broader populations rather than specific samples when considering interactive effects, particularly high-stakes individuals and the effect of arrest on their lives (Matthews and Agnew 2008). Other variables that should be considered are impulsivity and the ways in which impulsive individuals react to greater certainties of capture under different circumstances (i.e., whether different crimes have different outcomes), and consideration should be given to whether higher stakes people react differently from those with lower stakes given these circumstances.

Another area of expansion would be to provide interaction effects in deterrence research, since interactions hold enormous statistical power over other methods of analysis (Allison 1990). Interactive effects may be viewed between certainty and severity and its effect on criminal behavior, providing a clearer picture of deterrence in general. For example, Johnson (2006) investigated whether the effect of defendant's race on sentencing varied according to judge's race. First, he found that defendant's race/ethnicity had a generally positive effect on the incarceration decision. Black and Hispanic defendants were more likely than their white counterparts to be incarcerated. However, the effect of defendant's race on sentencing depended on the judge's race, such that as the dichotomous variable Minority Judge increased from 0 to 1 , the effect of defendant's race got less positive. Thus, Johnson concluded that although racial and ethnic disparity in sentencing was still present, there was less of it under minority judges (it was actually reduced by more than 
half). Such an example shows the importance of including interaction effects in one's study, and this method should be incorporated to better understand more complex relationships.

Additionally, future research should include a policy component regarding the effects of arrest. States are currently facing economic hardships and have sought ways to reduce expense, especially correctional budgets. California and Ohio are two states that are facing billions of dollars in budget shortfalls. A 2009 New York Times article noted that a panel of federal judges in California told the state to cut its prisoner populations by $27 \%$ in a two-year period (Moore, 2009). In Ohio, the Columbus Dispatch wrote that the prison chief there wants to reduce the number of prisoners by 2,000 with no plans for new prisons (Johnson, 2011). With states looking to shed expenses, reducing prison populations may appear to be the most logical step. Criminological research with a heavier focus on policy can not only further the discipline's mission, but also broaden the strength of theoryoriented research.

\section{REFERENCES}

Allison, Paul. 1999 Multiple Regression: A Primer. Thousand Oaks, California. Pine Forge Press.

Baumer, Eric. 2011 Uncertainty about reduced severity, concerns about increased certainty, and alternative path to lower rates of crime and punishment. Criminology and Public Policy. 10: 169-177.

http://dx.doi.org/10.1111/j.1745-9133.2010.00697.x

Berk, Richard A., Alec Campbell, Ruth Klap, and Bruce Western. 1992 A Bayesian analysis of the Colorado Springs spouse abuse experiment. The Journal of Criminal Law and Criminology 83: 170-200. http://dx.doi.org/10.2307/1143828

Briar, Scott and Irving Piliavin. 1965 Delinquency, situational inducements, and commitment to conformity. Social Problems 13 (1): 35-45. http://dx.doi.org/10.2307/799304

Buzawa, Eve and Carl Buzawa. 1996 Do Arrests and Restraining Orders Work? Thousand Oaks, CA: Sage Publications, Inc.

Buzawa, Eve and Carl Buzawa. 2003 Domestic Violence: The Criminal Justice Response. Third Ed. Thousand Oaks, CA: Sage Publications, Inc.

Cressey, Donald. 1978 Criminological Theory, Social Science, and the Repression of Crime. Criminology 16, 2: 171-191. http://dx.doi.org/10.1111/j.1745-9125.1978.tb00086.x

DeMaris, Alfred and Catherine Kaukinen. 2008 Partner's stake in conformity and abused wives' psychological trauma. Journal of Internpersonal Violence 23: 1323-1342. http://dx.doi.org/10.1177/0886260508314300

Hirschi, Travis. 1969 Causes of delinquency. Berkeley, CA: University of California Press.

Johnson, Alan. 2011 Sale of prisons, fewer inmates part of the budget plan. The Columbus Dispatch. Retrieved from: http://www.dispatchpolitics.com/live/content/local_news/storie s/2011/03/22/copy /sale-of-prisons-fewer-inmates-part-ofplan.html?adsec $=$ politics \&sid $=101$
Johnson, Devon. 2006 Crime salience, perceived racial bias and blacks' punitive attitudes. Journal of Ethnicity in Criminal Justice 4: 1-18. http://dx.doi.org/10.1300/J222v04n04 01

Kingsnorth, Rodney. 2006 Intimate partner violence: Predictors of recidivism in a sample of arrestees. Violence Against Women 12: 917-935. http://dx.doi.org/10.1177/1077801206293081

Kovandzic, Tomislav, Thomas B. Marvell, and Lynne M. Vieraitis. 2007 The Criminogenic effects of imprisonment: Evidence from state panel data, 1974-2002. Criminology and Public Policy 6: 589-622.

Laub, J. and R.J. Sampson. 1993 Turning points in the life course: Why change matters to the study of crime. Criminology 31 : 301-325. http://dx.doi.org/10.1111/j.1745-9125.1993.tb01132.x

Matthews, Shelley K., and Robert Agnew. 2008 Extending deterrence theory: Do delinquent peers condition the relationship between perceptions of getting caught and offending? Journal of Research in Crime and Delinquency 45: $91-118$

http://dx.doi.org/10.1177/0022427807313702

Maxson, Cheryl L., Kristy N. Matsuda, and Karen Hennigan. 2009 Deterrability among gang and nongang juvenile offenders: Are gang members more (or less) deterrable than other juvenile offenders. Crime and Delinquency: 1-28.

McGuire, William J. and P. Priestley. 1995 Reviewing "what works": Past, present, and future. [Review of book: What works: Reducing offending]. 3-34.

Moore, Solomon. 2009 California prisons must cut inmate population. The New York Times. Retrieved from: http://www.nytimes. com/2009/08/05/us/05calif.html

Nagin, Daniel, Francis Cullen, and Cheryl Jonson. 2009 Imprisonment and reoffending. Crime and Justice 38: 115200.

http://dx.doi.org/10.1086/599202

Nagin, Daniel, and Raymond Paternoster. 1994 Personal capital and social control: The deterrence implications of a theory of individual differences in criminal offending. Criminology 32 581-606.

http://dx.doi.org/10.1111/j.1745-9125.1994.tb01166.x

Nagin, Daniel and Greg Pogarsky. 2001 Integrating celerity, impulsivity, and extralegal sanction threats into a model of general deterrence theory and evidence. Criminology 39: 865-892.

http://dx.doi.org/10.1111/i.1745-9125.2001.tb00943.x

Pate, Anthony and Edwin E. Hamilton. 1992 Formal and informa deterrents to domestic violence: The Dade County spouse assault experiment. American Sociological Review 57: 691697.

\section{http://dx.doi.org/10.2307/2095922}

Paternoster, Raymond. 1987 The Deterrent effect of the perceived certainty and severity of punishment: A review of the evidence and issues. Justice Quarterly 4: 173-217. http://dx.doi.org/10.1080/07418828700089271

Paternoster, Raymond. 2010 How Much Do We Really Know About Criminal Deterrence? The Journal of Criminal Law and Criminology 100, 3: 765-824.

Piquero, Alex, Raymond Paternoster, Greg Pogarsky, and Thomas Loughran. 2011 Elaborating the Individual Difference Component in Deterrence Theory. Annual Review of Law and Social Science 7:335-360. http://dx.doi.org/10.1146/annurev-lawsocsci-102510-105404

Schmidt, Janell and Lawrence Sherman. 1996 Does Arrest Deter Domestic Violence? In Eve Buzawa and Carl Buzawa (Eds.), Do Arrests and Restraining Orders Work? (43-53). Thousand Oaks, CA: Sage Publications, Inc.

Sherman, Lawrence W., Janell D. Schmidt, Dennis P. Rogan, Douglas A. Smith, Patrick R. Gartin, Ellen G. Cohn, Dean J. 
Collins, and Anthony R. Bacich. 1992 The variable effects of arrest on criminal careers: The Milwaukee domestic violence experiment. The Journal of Criminal Law and Criminology 83:137-169.

http://dx.doi.org/10.2307/1143827

Sherman, Lawrence W., Douglas Smith, Janell D. Schmidt, and Dennis P. Rogan. 1992 Crime, punishment, and stake in conformity: Legal and informal control of domestic violence. American Sociological Review 57: 680-690. http://dx.doi.org/10.2307/2095921

Tonry, Michael and Joan Petersilia. 1999 Prisons. Chicago, IL: University of Chicago Press Journals.

Skardhamar, Torbjorn and Kjetil Telle. 2012 Post-release employment and recidivism in Norway. Journal of Quantitative Criminology: 1-21.

Spohn, Cassia. 2007 The deterrent effect of imprisonment and offenders' stakes in conformity. Criminal Justice Policy Review 18: 31-50. http://dx.doi.org/10.1177/0887403406294945

Toby, Jackson. 1957 The differential impact of family disorganization. American Sociological Review 22 (5): 505-512. http://dx.doi.org/10.2307/2089473

Vieraitis, Lynne, Tomislav Kovandzic, and Thomas Marvell. 2007 The criminogenic effects of imprisonment: evidence from state panel data, 1974-2002. Criminology and Public Policy 6: 589622.

http://dx.doi.org/10.1111/j.1745-9133.2007.00456.x

Wenzel, Michael M. 2004 The social side of sanctions: Personal and social norms as moderators of deterrence. Law and Human Behavior 28: 547-567. http://dx.doi.org/10.1023/B:LAHU.0000046433.57588.71

Wooldredge, John and Amy Thistlethwaite. 2002 Reconsidering domestic violence recidivism: Conditioned effects of legal controls by individual and aggregate levels of stake in conformity. Journal of Quantitative Criminology 18: 45-70. http://dx.doi.org/10.1023/A:1013292812895

Wright, Bradley R. E., Avshalom Caspi, Terrie E. Moffitt, and Ray Paternoster. 2004 Does the perceived risk of punishment deter criminally prone individuals? Rational choice, selfcontrol, and crime. Journal of Research in Crime and Delinquency 41: 180-213. http://dx.doi.org/10.1177/0022427803260263

Zimring, Franklin E. and Gordon J. Hawkins. 1968 Deterrence and Marginal Groups. Journal of Research in Crime and Delinquency 5:100-14. http://dx.doi.org/10.1177/002242786800500202

Received on 11-02-2013

Accepted on 02-10-2013

Published on 13-11-2013

DOI: http://dx.doi.org/10.6000/1929-4409.2013.02.45

(C) 2013 Christopher P. Rosbough; Licensee Lifescience Global.

This is an open access article licensed under the terms of the Creative Commons Attribution Non-Commercial License (http://creativecommons.org/licenses/by-nc/3.0/) which permits unrestricted, non-commercial use, distribution and reproduction in any medium, provided the work is properly cited. 